\title{
CLOTHES AS SYMBOLIC AND MAGIC OBJECTS IN SLAVIC CHILDBIRTH CUSTOMS ${ }^{1}$
}

\section{Irina Sedakova}

\begin{abstract}
The paper analyzes the practical, symbolic, and magic functions of female, male, and babies' clothes in Slavic childbirth-lore. Traditional clothes and their parts are seen as "objects and signs" (see, e.g., Bogatyrev 2007), and their cultural semantics and symbolism depend on the ritual situation, its performers, and magic goals. Each item of clothing has its own practical significance and acquires symbolic qualities which can be interpreted in terms of semiotic oppositions (life/death, lucky/unlucky, healthy/unhealthy, male/female, old/young). Special attention is paid to swaddles as the baby's first item of clothing. In the conclusion, the modern shift in attitudes to pregnancy clothing is analyzed, though it is noted that some authentic beliefs regarding clothes are still observed.
\end{abstract}

Keywords: childbirth customs, rituals, semiotic oppositions, Slavic folklore, traditional clothes

\section{INTRODUCTION}

This paper scrutinizes a number of topics regarding traditional folk costumes, and differs in its focus from the other articles in this thematic issue of Folklore: EJF. Central to this investigation are the symbolic and magic functions of traditional clothing, which are typical for rural societies across childbirth customs, magic acts, and Slavic beliefs. Childbirth-lore provides the researcher with a richly varied range of ways in which to study these questions. Besides other important reasons, it is due to the fact that the childbirth complex is regarded as a long period beginning with conception and lasting up to the age of one year. Thus there are many ritual situations, various actors and performers, and obstacles involved, which in their turn call for various clothing to be used. The key periods and temporal moments of crucial importance are: conception, pregnancy, delivery, first actions with the newborn, and the first 40 days of its life. They call for special attention regarding the choice of clothing (the color, cuts, fabric, way of preparation, etc.) and rituals involving them, as they are supposed to symbolize positive qualities and are thought to possess preventive 
and protective powers. These practices fit into the whole traditional childbirth ritual complex (Sedakova 2013).

The clothing in childbirth-lore demonstrates the semiotic essence of the costumes; items of clothing are seen as objects and signs in the terminology coined by Nina Gagen-Torn (1933), Galina Maslova (1984), and Piotr Bogatyrev (2007). Bogatyrev discusses the traditional everyday, festive, and ritual costumes (ibid.: 223) and constructs the hierarchy of the functions, which is different in every type of clothing. The everyday costume has the following functions: practical (to protect from the cold and heat); belonging (to demonstrate class and region); and esthetic. The festive costume reflects festive or solemn functions: esthetic; ritual; belonging (nation, region, class); practical. Finally, the ritual costume depicts ritual, festive, esthetic, national/regional/class belonging (to a negligible extent), and practical function (little or none) (Bogatyrev 2007: 232). In childbirth rituals and everyday care for the baby one can find elements of all the three groups, but they mainly reveal practical, ritual, esthetic, and occasionally also festive functions; they also demonstrate the gender and age differentiation. In some regions and religious groups (like among Old Believers) they include religious characteristics, which are of utmost significance.

A most important point concerning clothing at childbirth is that each item is seen not as a thing, but as having a magic function for various purposes. Everyday items of clothing like men's hats, trousers, and shirts, and women's aprons and skirts obtain magic power, whether similar to other life rituals or the calendrical circle, folk medical acts, etc., or develop a specific meaning. Some items of clothing which have acquired sacred power in one of the ritual complexes (Tolstoy \& Tolstaya 1994), for example, at a wedding, are frequently used for medical purposes at childbirth, both for the mother and the baby. A baby's shirt once used for christening is used for all the younger offspring in the family so that the sisters and brothers would love each other dearly. In Russia (Ryazan region), the wedding shirt of the father or even grandfather is used for these acts. The major ritual and magic characteristics are connected to the swaddling clothes and the belt - the baby's first clothes. They are used for a temporary period which is very important for the further development of the child. 


\section{SEMIOTIC ASPECTS AND ARCHAIC SYMBOLISM OF CLOTHES IN CHILDBIRTH-LORE}

In childbirth customs rituals, clothes and parts thereof are often used as pure signs. Occasionally they do not have any practical value, apart from the fact that they belong to a particular person. So the owner's characteristics, qualities, and special status (pregnancy) are of great importance here. Frequently clothes can stand in for the person, like in the Russian North; when the baby is delivered (traditionally in a sauna), an item of the mother's clothing is put outside the window. This means that the secret time of when the delivery takes place is over, and the mother and baby can now accept guests.

Such characteristics like gender, family relation to the baby (sisters and brothers, mother and father, grandmother and grandfather), age (old people's clothes are valuable), color, and size play a significant role in the ritual childbirth complex.

A well-known Slavic belief is that to conceive a baby of certain sex, male or female items of clothes should be worn during sexual contact. If a couple wants a girl, the man puts on a women's shawl, if they want a boy, the woman wears a man's hat. Through the clothes some traces of couvade can be revealed - during the delivery the husband puts on his wife's clothes, even a shawl on his head, and groans. The woman in birth is made to walk over the pants of her husband, so as to make the delivery easier (Vlasova 2001: 585). The newborn is wrapped in its father's shirt - so as to be healthy and live long years, be brave, etc. If in a family babies have died one after another, when the next baby is delivered, the midwife will take it with the father's pants to make it strong. The pants also have an apotropaic, guarding function by substituting the strong man guarding the baby: usually the father's trousers or another male garment is hung on the door of the room in which the baby sleeps, or on its bed (Ukraintsy 2000: 310). Occasionally the gender of the newborn is taken into consideration: the girl is put into her mother's shirt, while a boy is put in his father's shirt (Ukraintsy 2000: 619; Kabakova 2001: 97).

The age and the opposition old/young correspond to the length of the baby's adult life. One interpretation for using old items of clothing (not definitely worn by relatives) for the first swaddle is that they are old, so the baby will live a long life until his or her old age, and will not die young in an accident or because of an illness. It alludes to the core of childbirth and reflects the important life/death opposition. In the archaic worldview, early death is explained by the evil eye, the activity of demons and evil spirits, and the wrong behavior of the motherto-be and other people around. The pregnant woman should hide her abdomen, which is why traditionally they wear dresses with a special cut, which do not 


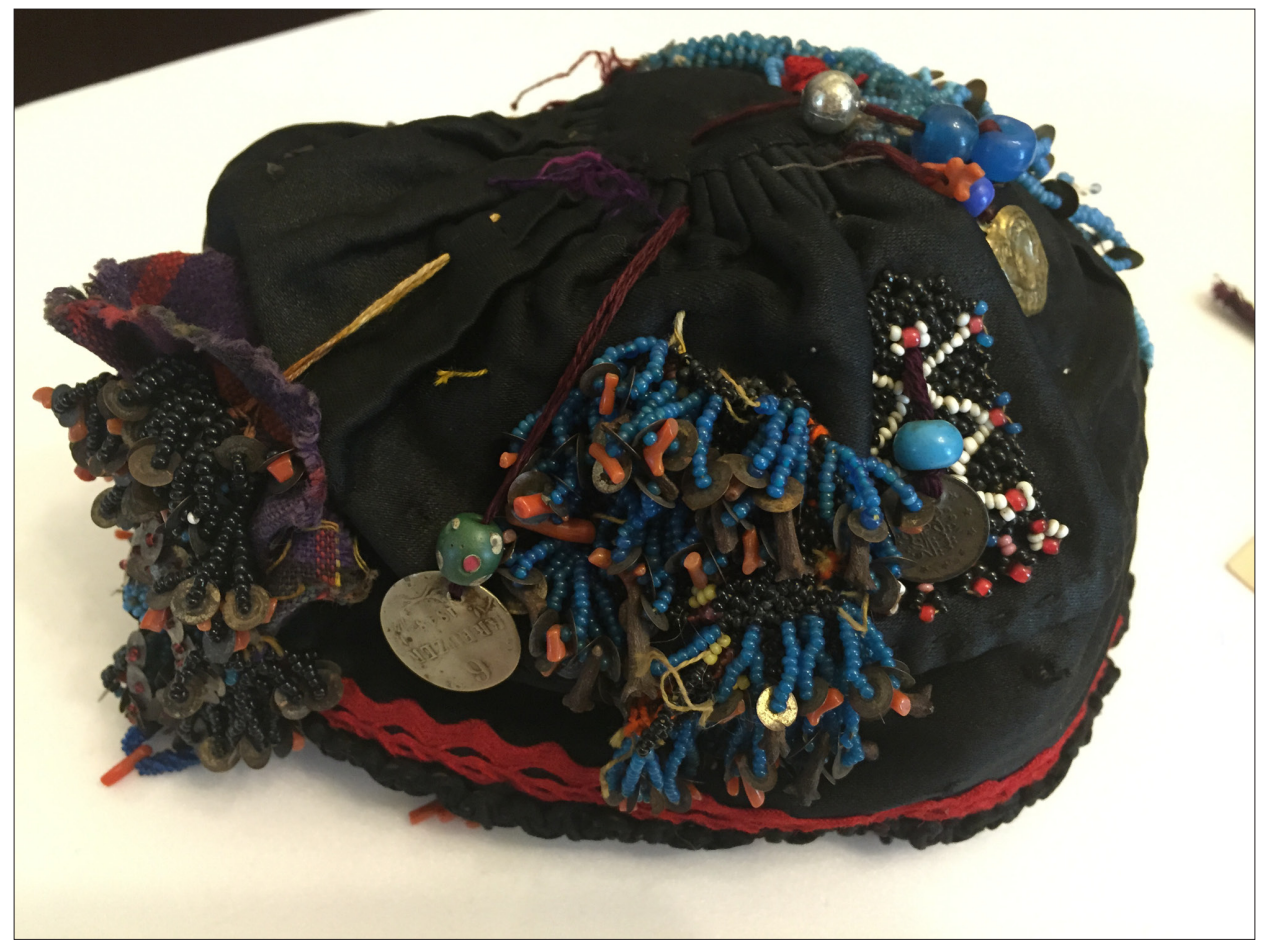

Figure 1. Baby's cap with many protective amulets. Village of Podvis, Karnobat region, Bulgaria. Museum of Ethnography, Sofia, Bulgaria. Photograph by Irina Sedakova 2015.

show the size and the shape of the growing belly. She wears a pair of each items of clothing, like two aprons, two shawls, and two skirts, so as to keep the baby alive (compare: she also uses two spoons while eating (SD 1995: 161)). From the moment the baby is born up to the 40th day the mother should not wear bright colors or jewelry, so as to avoid attention of the evil eye. Meanwhile the baby's clothes, especially for going out, are decorated with protective amulets (a cross, silver coins, pearls, shells, 'blue eyes' made of glass, and other). Special baby's caps with many amulets can still be discovered in rural areas (see, for example, the cap decorated with protective amulets (Fig. 1) from the Museum of Ethnography in Sofia). ${ }^{2}$

While showing me the collection of the headwear, one of the museum workers told me an interesting story. When her grandson was born in Sofia in 2010, her daughter wanted to use only modern brand items for the baby. The great-grandmother objected and made a special cap with amulets for her great-grandson. So the protective symbolism of amulets is still being observed even in big cities. 
Babies' items of underwear are put on inside out, and a safety pin pierced into a swaddle is also used against the evil eye and illnesses.

Protective, apotropaic, and productive magic measures are taken during the whole period of the childbirth ritual complex, and are often linked to the color of the clothes or a part thereof. Main semiotic oppositions here are white/black (as life/death, lucky/unlucky) and blue/pink (as male/female). The color black alludes to death, mourning, and funerals - the swaddles and the ribbons are never made of black or dark (dark blue) cloth. The black color also alludes to an unlucky life. A Bulgarian dialectal expression goes: "Why are you so unlucky? Probably your mother wrapped you in black clothes with not a single white thread" (Rks 336). The color black is used only for burial wraps in the case of a baby's death (Rks 102, 103).

Apart from symbolic meaning, the color white has a very practical purpose which, as it is typical for traditional rural culture, is achieved with magic acts. Traditionally, the mother's wish is that the clothes of the baby would be clean and white like snow. Usually after the christening, on her way home, the mother visits several houses where she is given white objects and food - an egg, sugar, etc. The egg is used for washing and bathing the baby. The same rituals are found to be spread over almost all of Europe.

Another color opposition is blue/pink (as male/female), correspondingly boys' swaddles and clothes are blue, while those of girls are pink. This color division is documented by P. Bogatyrev in the Carpathian villages in the $1930 \mathrm{~s}$, especially for the christening dresses (Bogatyrev 2007: 249-250). This symbolic color denoting gender has eventually become more and more popular and has today spread far from just childbirth customs and costumes.

An interesting development of gender restrictions in the usage of color can be found in Sakar (Bulgaria), where there are documented restrictions with the embroidery for the christening costume. It is forbidden to use plenty of red in a girl's dress, so that in her adult life her menses would not last for too many days (Popov \& Grebenarova 2002: 261).

\section{SWADDLES}

Swaddles are the baby's traditional items of clothing and come in various types: light, warm, everyday, and festive (for christening, for going out after the 40th day). They have practical, ritual, gender denoting, and esthetic functions. One of the main characteristics of swaddles is as the baby's first item of clothing, and it is this which gives us the Slavic words for the newborn: Russian pelenishnyi, Bulgarian pelenache, pelenak ('the one with swaddles'). Formerly, midwives 
used to swaddle the baby tightly, covering its body, legs, and hands. Nowadays it is rare in modern cities to find babies wrapped this way; they are dressed so as to move freely.

The swaddles are in the focus of attention of the mother and other family members regarding the fabric, temporal preparation of the wraps, washing of and contact with them, etc.

The fabric lies in direct contact with the body, so much attention is paid to it in terms of the possibility of contagious magic effects. It is believed that via swaddles many important qualities can be passed to the newborn: features of the swaddle (color, fabric, size, etc.) can influence the development of the baby and its future adult life. It is believed that via swaddles illnesses can be passed on, and evil spirits can harm the babies. This is why they are rubbed with onions, and occasionally garlic; red threads, small iron bits, salt, or bread is put into the swaddles to prevent the evil spirits or the evil eye from harming the baby. To bring wealth, the Polish put a coin into the baby's swaddles.

Each bride should have swaddles in her dowry, but during pregnancy the woman is not allowed to make them; usually her mother or mother-in-law does this. Some swaddles should be brought by the midwife when she comes to deliver the baby (Mikhailova \& Popov 1999: 209). The first wraps are often made of old fabric or pieces of clothing, e.g. of mother's apron (Khadzhinikolov 1980: 245), or from pieces of a garment of a good-natured relative (Mikhailova \& Popov 1999: 209). The first swaddles are not torn, but usually cut with scissors; otherwise the baby will talk in the night. In Serbia, the first swaddling act is performed on the earth; a sieve as a symbol of prosperous life is held above the baby. Each time when the baby's swaddles are changed, the mother or any other person blesses it, reads prayers, and makes a cross on it; occasionally they spit to the left (Naumenko 1998: 31).

Swaddles are often used in folk medical rituals, where they substitute the baby, being its most important item of clothing. In some countries, it is customary to leave swaddles of an ill baby on the icon of saints and the Virgin Mary for the night (SD 2004: 659). Leaving the swaddle of a baby who suffers from insomnia and cries a lot in the woods is a typical Balkan and South Slavic folk medical practice. The swaddles of a baby whose mother does not have enough milk are dowsed with holy water, or are put into a fast-flowing river, so the milk will flow rapidly and in large amounts (Sedakova 2011). In Serbia, there is a belief that if a mother has only daughters and she wants a son, she should steal a swaddle from a mother who gives birth to only boys, and then she will have a son (Trebjeshanin 2000 [1991]: 45).

There are other recommendations and strict rules regarding swaddles. The mother should not sit on swaddles, since she is seen as 'impure', so the skin of 
the baby will be unclean. For 40 days they are never washed or dried outside, and nobody should see them (Vlasova 2001: 619). They are never left outside after the sunset, because in the dark evil spirits can harm the babies through their swaddles, make them sleepless and weepy (Mikhailova \& Popov 1999: 209). In Bulgaria washed swaddles are put on fruit trees, so the baby will have children in his adult life (Popov \& Grebenarova 1994: 129).

Another item of the baby's clothing is the belt. This is a long piece of fabric put over the swaddle, occasionally making a cross. There are some accounts that claim this is for the baby to have a strong back, and straight hands and legs. In Bulgaria, it should not be too long, otherwise the wedding in the future will be a late one. In Russia, the belt should be long enough, so that the life of the baby will be long.

\section{CONCLUSION}

Through the analysis of the clothing used in the period of childbirth we have found further confirmation of Bogatyrev's ideas on traditional clothing, in which he suggests treating items of clothing not as things but as signs. Furthermore, the complex interrelatedness of the artifacts as they are understood in traditional folk culture becomes evident. Thus childbirth clothing is connected specifically with that of weddings and funerals. Babies' wraps bear a resemblance to funeral veils and clothing for the dead. The family festival of childbirth with a show of many clothes given as gifts by the guests is like the wedding show of the bride's dowry.

Nowadays rural practices have changed as a result of medical and technical developments, changes in mentality, and urbanization. It is my firm belief that studies of modern culture and change are much more fruitful when based on a profound knowledge of authentic rural tradition. That is why this article examines practices which are seen as, so to say, remnants, superstitions. To a certain extent this field data can be registered in rural and even urban areas, as a memory rather than a practice.

My final remarks consider changes in the very sacred meaning of childbirth customs. Modern fashion clothing does not hide but rather demonstrates pregnancy, because nowadays the mother-to-be shows that she is proud of her state.

There are almost no bans on the mother-to-be from openly preparing the baby's first clothes before it is born. This has become a part of family planning. The sex of the baby is learnt early on in the pregnancy, so the color of the clothes and other things being prepared beforehand can correspond to its gender. 


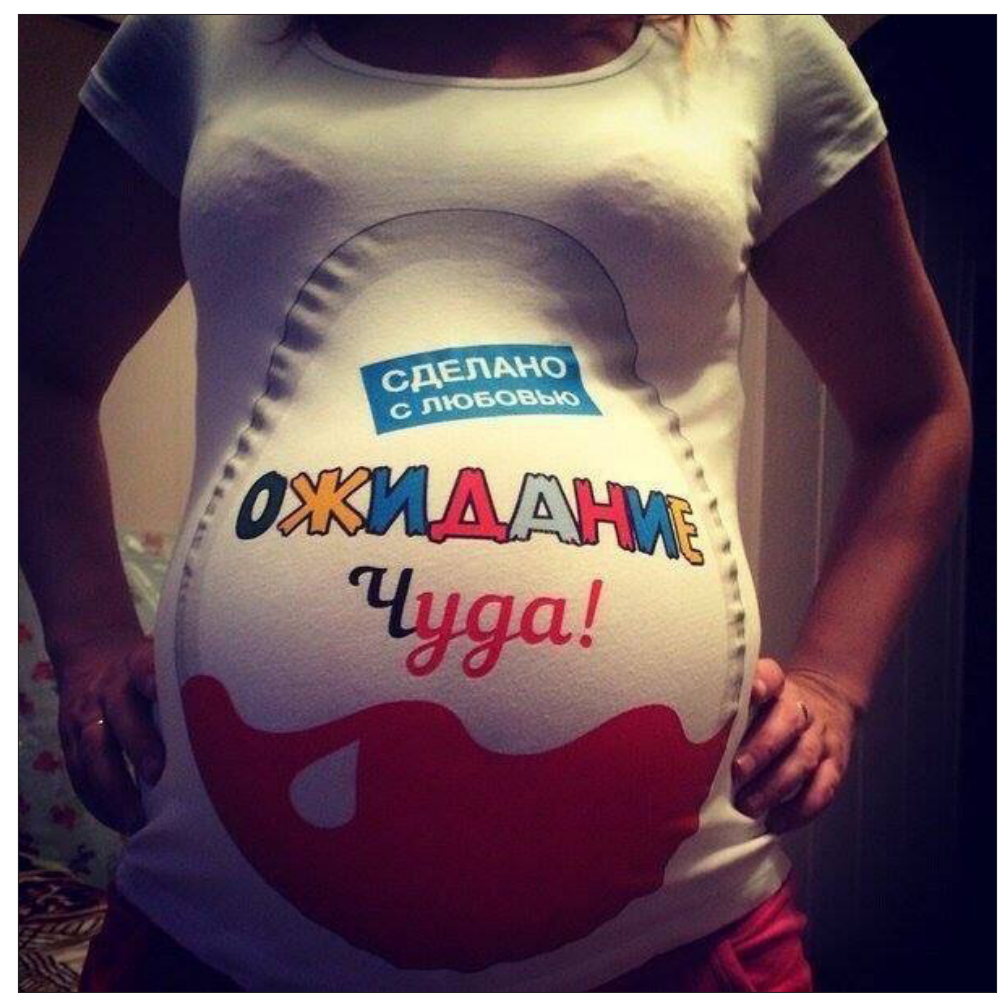

Figure 2. T-shirt "Waiting for a miracle" for pregnant women. (http: / / dbkids. ru/products / futbolka-dlya-beremennyhTDPG044).

The families who are waiting for a baby to be born organize special parties (baby showers). This idea and practice originate in the USA. Today the tradition of celebrating a baby shower has spread all over the world (Ekrem 2013). In Russia, these parties are known as 'pre-birthday party', 'minus birthday party', 'the stork holiday', etc. Many details of these parties are contrary to traditional views on pregnancy and childbirth, but some of them are still based on rural practices.

\section{NOTES}

1 This research was financially supported by the Russian Humanitarian Foundation (project № 14-04-00546a, "Linguistic-cultural situation in Russia and Bulgaria and transformation of the Russian-Bulgarian language interrelations: 21st century"). 
${ }^{2}$ I am grateful to my Bulgarian colleagues Dr Petko Khristov and Dr Elena Vodenichar from the Institute for Ethnology and Folklore Studies with Ethnographic Museum in Sofia (http://iefem.bas.bg/), who gave me permission to see the collection and to publish the picture of one of the collected items.

\section{ARCHIVAL SOURCES}

Rks = Archival collection of graduate theses written under the guidance of Academician Stefan Romanski. Sofia University "St. Kliment Ohridski".

\section{REFERENCES}

Bogatyrev, Piotr 2007. Funktsii natsional'nogo kostiuma v Moravskoi Slovakii. [Functions of the National Costume in Moravian Slovakia.] In: P. Bogatyrev Narodnaia kul'tura slavian. [Folk Culture of the Slavs.] Moscow: OGI, pp. 215-279. Available at http://maxima-library.org/mob/b/342594, last accessed on November 17, 2016.

Ekrem, Carola 2013. Baby Showers - An Innovation in the Finnish Festival Year. In: A. Vaicekauskas (ed.) The Ritual Year 5: The Power of the Mask. Kaunas: Vitautas Magnus University, pp. 90-98.

Gagen-Torn, Nina 1933. K metodike izucheniia odezhdy v etnografii SSSR. [Towards the Methodology of Costume Studies in the USSR.] Sovetskaia etnografiia, № 3-4, pp. 38-46.

Kabakova, Galina 2001. Antropologiia zhenskogo tela v slavianskoi traditsii. [Anthropology of Female Body in Slavic Tradition.] Moscow: Ladomir.

Khadzhinikolov, Veselin (chief ed.) 1980. Pirinski krai: Etnografski, folklorni i ezikovi prouchvaniia. [Pirinski Region: Ethnographic, Folkloric and Linguistic Studies.] Sofia: Izdatelstvo na BAN.

Maslova, Galina 1984. Narodnaia odezhda v vostochnoslavianskikh traditsionnykh obychaiakh i obriadakh XIX - nachala XX veka. [Folk Costumes in the East Slavic Traditional Customs and Rituals of the 19th - Beginning of the 20th Centuries.] Moscow: Nauka. Available at https://vk.com/doc-41371964_437077460?dl=c2ccf $5 \mathrm{~d} 13 \mathrm{e} 1 \mathrm{~d} 76 \mathrm{~d} 295$, last accessed on November 21, 2016.

Mikhailova, Ganka \& Popov, Rachko (eds.) 1999. Loveshki krai: Materialna i dukhovna kultura. [Loveshki Region: Material and Spiritual Culture.] Sofia: Izdatelstvo na BAN.

Naumenko, Georgy 1998. Etnografiia detstva: Sbornik fol'klornykh i etnograficheskikh materialov. [Ethnography of Childhood: Collection of Folkloric and Ethnographic Materials.]. Moscow: Belovod'e. Available at http://www.ruthenia.ru/folklore/ folklorelaboratory/4expseminar/Naumenko_Etn_det.pdf, last accessed on November 21, 2016.

Popov, Rachko \& Grebenarova, Slavka (eds.) 1994. Rodopi: Traditsionna narodna dukhovna $i$ sotsialnonormativna kultura. [Rhodopes: Traditional Folk Spiritual and Social-Normative Culture.] Sofia: Izdatelstvo na BAN. 
Popov, Rachko \& Grebenarova, Slavka (eds.) 2002. Sakar: Etnografsko, folklorno i ezikovo izsledvane. [Sakar: Ethnographic, Folkloric and Linguistic Studies.] Sofia: Izdatelstvo na BAN.

SD 1995 = Slavianskie drevnosti: Etnolingvisticheskii slovar'. [Slavic Antiquities: Ethnolinguistic Dictionary.] Vol. 1 (A-G). Moscow: Mezhdunarodnye otnosheniia. Available at https://yadi.sk/d/B_y1fp26SjKjR, last accessed on November 21, 2016.

SD 2004 = Slavianskie drevnosti: Etnolingvisticheskii slovar'. [Slavic Antiquities: Ethnolinguistic Dictionary.] Vol. 3 (K-P). Moscow: Mezhdunarodnye otnosheniia.

Sedakova, Irina 2011. Grudnoe moloko kak mifologema: etnolingvisticheskie aspekty. [Breast Milk as a Mythologem (on the Bulgarian Folk Traditional Data.] In: N. Zlydneva (ed.) Kody povsednevnosti v slavianskoi kul'ture: Eda i odezhda. St. Petersburg: Aleteiia, pp. 77-90.

Sedakova, Irina 2013. Balkanski motivi v ezika i kulturata na balgarite: Razhdane $i$ sadba. [Balkan Motifs in Bulgarian Language and Culture: Childbirth and Fate.] Sofia: Izdatelstvo BAN.

Tolstoy \& Tolstaya 1994 = Tolstoi, Nikita \& Tolstaia, Svetlana. O vtorichnoi funktsii obriadovogo simvola (na materiale slavianskoi narodnoi traditsii). [On the Secondary Function of a Ritual Symbol: Based on Slavic Folk Traditional Data).] In: V. Petrukhin (comp.) Istoriko-etnograficheskie issledovaniia po fol'kloru. Sbornik statei pamiati Sergeia Aleksandrovicha Tokareva. Moscow: Vostochnaia literatura, pp. 238-256.

Trebjeshanin, Zharko 2000 [1991]. Predstava o detetu u srpskoj kulturi. [Views on the Baby in Traditional Culture.] 2nd edition. Beograd: Jugoslovenski tsentar za prava deteta.

Ukraintsy $2000=$ Ukraintsy. [The Ukrainians.] Seriia "Narody i kul'tury". [Series "Peoples and Cultures".] Moscow: Nauka.

Vlasova, Irina (chief ed.) 2001. Russkii Sever: Etnicheskaia istoriia i narodnaia kul'tura XII -XX vekov. [Russian North: Ethnic History and Folk Culture of the 12th-20th cc.] Moscow: Nauka. Available at http://www.booksite.ru/fulltext/nor/thr/uss/, last accessed on November 21, 2016. 